\title{
Determinants of Utilization of Financial Management Information Technology System Utilization on Financial Report Quality of Enrekang Regency
}

\author{
Nurfadilah ${ }^{1}$, Osman Lewangka², Yunus Amar ${ }^{3}$ \\ \{Nfdilah92.dhila@gmail.com ${ }^{1}$, osmanlewangka@yahoo.co.id ${ }^{2}$, myunmar@gmail.com ${ }^{3}$ \} \\ Universitas Hasanuddin, Makassar, Indonesia ${ }^{1,2,3}$
}

\begin{abstract}
This study examines the effect of human resources on performance expectancy, social influences, facilitating conditions, use behavior, and system quality by making use of information technology systems of regional finance to produce a qualified financial report in the government of Enrekang Regency. The object of this research states the civil apparatus having a position in the financial management unit consisting of 31 OPD. The sample consisted of 95 respondents selected proportionally. The result of the study indicate that (1) performance expectancy has a positive and significant on the quality of the financial report, (2) social influence does not significantly effect of the quality of the financial report, (3) facilitating conditions has a positive and significant effect on the quality of financial report, (4) use behavior has a positive and significant effect on the quality of the financial report, and (5) system quality has a positive and significant effect on the quality of the financial report
\end{abstract}

Keywords: Performance expectancy, Social influence, facilitating conditions, Use behavior and System quality

\section{Introduction}

The development of science and technology at this time has provided opportunities in various activities. Both are engaged in business activities and in government organizations. With the rapid growth of science and technology, every company or organization must prepare itself in the face of increasingly fierce competition.

In carrying out government activities and public services (public service), local finance becomes the holder of a very important role. Therefore, the management must be carried out effectively and efficiently to be effective and successful. The manager must be able to provide the necessary financial information that is accurate, relevant, timely, and reliable in order to support the implementation of regional autonomy. According to Dewi, et al. [1], the regional financial system that is reliable and relevant reporting are required so that the later can provide information that can be justified.

The phenomenon of the poor quality of financial statements requires that each financial manager must have a good knowledge of financial statements so that published reports can be presented fairly free from material errors in the presentation of figures, which are not in accordance with reporting. So that can have a bad impact on the report users and the report presenters themselves. 
Referring to the LK audit conducted by the BPK on the State Financial Examination Standards (SPKN) stipulated in BPK Regulation Number 1 of 2007, based on that reporting on the audit results of the Government Financial statements on the type of opinion. There are four types of views that can be given by audit, namely: unqualified opinion (WTP), qualified Opinion (WDP), adverse opinion (TW), disclaimer/no opinion (TMP).

The use of technology in information systems should consider the user (user) because as time goes by it is not seldom to find that the technology applied in the information system is frequently not appropriate or it is not maximally utilized by the individual user of information the system so that the information system does not give the sufficient utilization in improving the individual performance. Information technology is a very supporting factor in the information system application representing an organization's management approach in solving the existing financial reporting problems.

The importance of information technology today is much felt by users of information technology in a company or government, especially in the financial sector. There are several online and offline applications that are used by the Enrekang District Government in managing their regional finances. The habit of utilizing Financial Information Technology Systems is still lacking; there are still some employees who have not been active in using information technology, as seen from the work facilities of employees who still do not have computers or other information technology tools. This also becomes one of the reasons why employees are not fully able to utilize information technology in their work.

This research discusses the influence of performance expectations (performance expectancy), coworkers (social influence), technological facilities that support (facilitating conditions), interest in utilization, and quality of technology system. It is expected that applying the UTAUT model can explain the behavior of financial information technology utilization while the independent variable is the quality of the financial statements. But to adjust to the situation and condition of the research environment, in this study, the researchers did not use the moderator variable.

In this regard, several studies have been conducted that reveal the extent to which employees use information technology systems. Government financial statements are a representation of the financial position of transactions carried out by a government. To be able to produce financial statements, of course, requires adequate infrastructure, accompanied by learning of human resources that are owned by in order to understand and implement a new system of financial management.

By considering the background and previous studies, the authors are motivated to conduct this research to obtain evidence of the influence of performance expectations, coworkers, technological support, interest in utilization, and quality of the system.

\section{Research Method}

This was quantitative research. Quantitative research is a process of finding out the knowledge using the data in the form of the figures as the instrument to find out information regarding the objectives of the research. Related to this, this type of research uses a questionnaire or observation and a brief interview. A questionnaire containing 29 question items was distributed to respondents who were involved in the financial management process, namely the head of finance and the staff at the OPD (regional device organizations) in Enrekang. The questionnaires used in the analysis of this research model were 95 
questionnaires according to the number of respondents; this type of research is nonexperimental because there is no respondent special treatment. The validity of the data in this study was tested using the SPSS 20.0 software application.

\section{Findings}

Table 1. The Result of F-Test

\begin{tabular}{|c|c|c|c|c|c|c|}
\hline \multicolumn{2}{|c|}{ Model } & \multirow{2}{*}{$\begin{array}{r}\text { Sum of Squares } \\
946.273\end{array}$} & \multirow{2}{*}{ Df } & \multirow{2}{*}{$\begin{array}{r}\text { Mean Square } \\
189.255\end{array}$} & \multirow{2}{*}{$\begin{array}{l}\mathrm{F} \\
69.912\end{array}$} & \multirow{2}{*}{$\begin{array}{l}\text { Sig. } \\
.000^{\mathrm{l}}\end{array}$} \\
\hline 1 & Regression & & & & & \\
\hline & Residual & 240.927 & 89 & 2.707 & & \\
\hline & Total & 1187.200 & 94 & & & \\
\hline \multicolumn{7}{|c|}{$\begin{array}{l}\text { a. Dependent Variable: The quality of financial statements (Y) } \\
\text { b. Predictors: (Constant), performance expectancy (X1), coworkers (X2), Facilitating } \\
\text { conditions (X3), interest in utilization(X4), and the quality of technology } \\
\text { system(X5). }\end{array}$} \\
\hline
\end{tabular}

Based on the results obtained in Table 1 , it is known that the significance level of hypothesis testing is, that is, the significance level of $0.00 \leq \alpha=0.05$.

It can be concluded that the hypothesis is accepted or, in other words, performance expectancy, coworkers, technology facilities, interest in utilization, and the quality of technology system simultaneously have a positive and significant effect on the quality of financial statements.

It means that, with the high knowledge of regional financial management, it would show that each Regional Device Organizations is able to compile financial statements in accordance with government regulation no. 24 the year 2005 .

Table 2. The Result of T-test

\begin{tabular}{|c|c|c|c|c|c|c|}
\hline \multirow{2}{*}{\multicolumn{2}{|c|}{ Model }} & \multicolumn{2}{|c|}{$\begin{array}{l}\text { Unstandardized } \\
\text { Coefficients }\end{array}$} & \multirow{2}{*}{$\begin{array}{c}\text { Standardized } \\
\text { Coefficients } \\
\text { Beta }\end{array}$} & \multirow{3}{*}{$\frac{\mathrm{T}}{1.984}$} & \multirow{3}{*}{$\begin{array}{l}\text { Sig. } \\
.050\end{array}$} \\
\hline & & B & Std. Error & & & \\
\hline \multirow[t]{3}{*}{1} & (Constant) & 3.122 & 1.573 & & & \\
\hline & $\begin{array}{l}\text { Performance } \\
\text { Expectancy } \\
\text { (X1) }\end{array}$ & .347 & .084 & .282 & 4.136 & .000 \\
\hline & $\begin{array}{l}\text { Co-Workers } \\
\text { (X2) }\end{array}$ & .056 & .051 & .057 & 1.093 & .277 \\
\hline
\end{tabular}




\begin{tabular}{llllll}
\hline $\begin{array}{l}\text { Facilitating } \\
\text { Conditions } \\
\text { (X3) }\end{array}$ & .180 & .074 & .138 & 2.436 & .017 \\
& & & & & \\
$\begin{array}{l}\text { Interest in } \\
\text { Utilization } \\
\text { (X4) }\end{array}$ & .294 & .090 & .204 & 3.284 & .001 \\
& & & & & \\
The Quality Of & .533 & .078 & .439 & 6.801 & .000 \\
Technology & & & & & \\
System (X5) & & & & & \\
a. Dependent Variable: The quality of financial statements (Y) & & & & \\
\hline
\end{tabular}

Based on the results obtained in Table 2 shows that the significant influence of on performances expectancy, coworkers, technology facilities, interest in utilization, and the quality of technology system on the quality of financial statements, the work expectation variable obtained a significance value of $0.000<\alpha=0.05$, conditions variables that facilitate significance value obtained $0.017<\alpha=0.05$, the variable use interest obtained a significance value of $0.001<\alpha=0.05$. and the variable interest in use obtained a significance value of $0,000<\alpha=0.05$. It can be concluded that the hypothesis is accepted or, in other words, on performance expectancy, coworkers, technology facilities, interest in utilization, and the quality of technology system partially have a positive and significant effect on the quality of financial statements. Whereas the variable coworkers obtained a significant value of $0.277>\alpha$ $=0.05$, which means that the coworker variable does not significantly influence the quality of financial statements.

Based on the results of the F-test and the t-test described above, the results of testing this research model can be presented in the following figure:

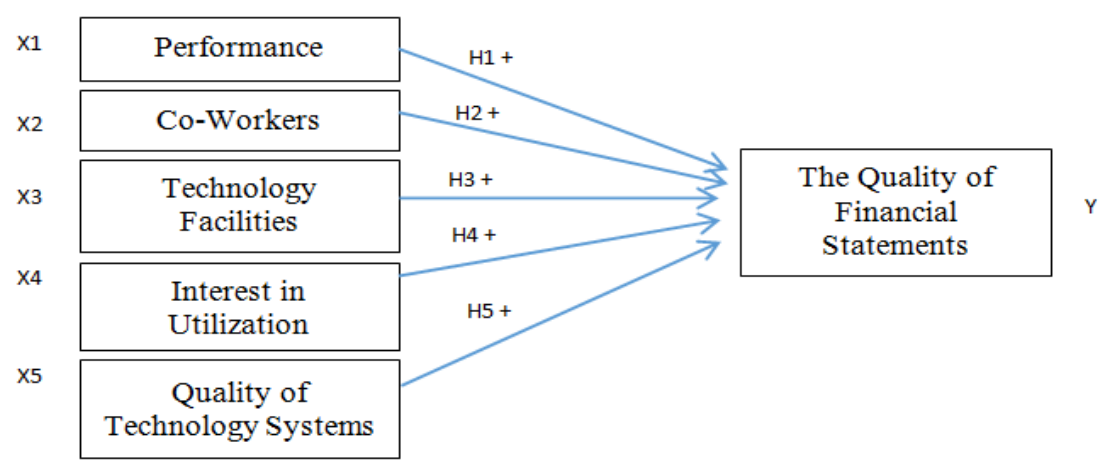

Fig. 1. Conceptual Framework using the UTAUT Model 


\section{Discussion}

\subsection{The Effects of Performance Expectations (X1) on Financial Report Quality (Y) in Enrekang Regency}

Performance expectancy of Information Technology Systems significantly affects the quality of financial statements. Local Government Agencies in the regional government of Enrekang Regency use Technology systems. This is in accordance with the theories used to obtain the factors of performance expectancy, namely: 1) Perceived usefulness in TAM, to what extent someone believes that using a particular system will improve his or her work performance. 2) relative advantage in IDT, to what extent the implementation of innovation perceived better than using its predecessor. 3) The outcome expectancy in SCT, outcome expectations is related to the consequences of the use of technology on performance expectancy and personal performance expectancy. 4) Extrinsic motivation in MM, the perception desired by the user to carry out activity because it is considered as a tool in achieving valuable results that are different from the activity because it is considered as a tool in achieving different results from the activity itself, such as, work performance and promotions. 5) The job-fit in MPCU, work suitability, which is seen from the capabilities of a system in increasing individual work performance.

\subsection{Effects of Coworkers (X2) on Financial Report Quality (Y) in Enrekang Regency}

Based on the test results of hypothesis 2, it showed that the proposed hypothesis is rejected. The output shows that the t-statistic value for the construct of the effects of coworkers on the quality of financial statements to utilize the Financial Technology System is smaller than the t-table value (1.093), which is 1.984 , so that the effect given by colleagues on financial report quality is proven insignificant.

This indicates coworkers (RK) do not significantly affect the quality of financial statements to utilize financial information technology systems. This is in accordance with the theory found by Venkatesh et al. [2], when studying the model analyzed to create UTAUT [2]. They claim that this happens because the probability of someone to fulfill someone else's expectations is greater when someone is able to give a gift [2].

Analyzed use of Internet banking in the elderly. He found that social norms, in this case, the effects of coworkers is a variable that has less significant influence compared to other variables. On the other hand, Yuen et al. (2010) analyzed the factors that affect the acceptance of developed countries and developing countries using UTAUT model, which also found that coworkers (Social Influence) did not affect one's desire to use the system in both countries. They further explain that friends do not have a significant influence on the decision to use the internet because users tend to access it themselves for security reasons. According to them, it is different from banking technology systems; another information technology has an important social effect because some applications become more useful when there are more users, and users try to encourage people they know to use the application. 


\subsection{Effects of Supporting Technology Facilities (X3) on Financial Report Quality (Y) in Enrekang Regency}

Based on the test results of hypothesis 3, it shows that the proposed could be accepted. This indicated that the variable of technology facility support has a significant and positive effect on the quality of financial statements.

The technology facilities factor got a t-table of 2.436 or was rounded up to 2.4 . Thus, the regional financial management system in terms of the variable of supporting technology facilities (Facilitating Conditions) showed strongly agree and agree. This means that technical support has a good value for the utilization and acceptance of regional financial management technology application systems in the Enrekang Regency.

From the results, it can be interpreted that the amount of acceptance of technological support to the quality of financial statements is satisfactory. Therefore, it can be concluded that the supporting technology facilities variable is a good factor and needs to be improved in producing qualified financial reports.

\subsection{Effects of Interest in the Utilization of Information Technology (X4) on Financial Report Quality (Y) in Enrekang Regency}

From the testing result of hypothesis 4 , there is evidence indicating the significant effect between the information technology utilization interest and financial report quality, and their correlation is positive. The greater the influence of the information technology utilization on the financial report quality, the better the financial report quality value produced by the government. The respondents' confession that the new technology system use is very different from old IT. The old IT limitations are difficulty in reading the database in the server, the inability of Old IT to become the support. By the use of the new IT, IT users have more spirit to use it because the old IT limitations can be overcome by the new IT.

The research is consistent with the finding of Venkatesh et al. [2], which states that there is a direct and significant correlation between IT utilization interest and information system use. To improve the final users' spirit to accomplish their work, their interest must previously be improved on IT use.

\subsection{Effects of the Quality of Technology System (X5) on Financial Report Quality (Y) in Enrekang Regency}

The test results of Hypothesis 5 are the Information Technology Quality has a significant and positive effect on the quality of financial statements. The results of multiple linear regression show that the effect of technology quality on report quality with the help of SPSS 20.0 for windows. The amount of the $t$-test was 6.81 . It means that if the quality of the information technology system is good, then it would affect the quality of the financial statements. Thus, H5 is accepted. Significant test results of $t$ on the quality of information technology variable obtain a significant level of 6.80 , which is smaller than 1.98 , which means that the quality of information technology has a significant and positive effect on the quality of financial statements. Therefore, H5 is accepted.

The quality of information technology systems has a positive influence on the quality of financial statements. The results of the study also support the results of research conducted, which states that the quality of the technology system has a significant effect on the quality of 
financial statements. The results of the data analysis state that the higher the quality of the information technology system, the higher the quality of the financial statements.

\section{Conclusion and Suggestions}

\subsection{Conclusion}

Based on the results of research and discussion, it can be concluded as follows:

1. Performance expectancy has a positive and significant effect on the quality of financial statements. Respondents believe that using a technology system would help to increase profits when attaching financial reporting results.

2. Coworkers have an insignificant effect on the financial report quality in the utilization of the financial information technology system. The social or work environment, in this case, Coworkers, does fully comprehend the technology system used.

3. Supporting technology facilities have a positive and significant influence on the quality of financial reports in utilizing financial management information technology systems. The more respondents supporting facilities such as training and better service access, respondents tend to produce more qualified financial reports.

4. Interest in utilization has a positive and significant effect on the quality of financial statements. Respondents have the intention and interest to utilize financial management information technology systems.

5. The system quality (SQ) has a positive and significant impact on the financial report quality. Respondents feel that the report presented by the system (application) has met the quality standards in regional financial reporting.

\subsection{Suggestions}

Based on the research limitations, the suggestions which can be proposed are as follows:

1. For the needs of future studies, it is advised to the researchers to accompany the respondents and conduct an interview process in the process of filling out the questionnaire to minimize bias towards the results of the study due to the respondents' conditions that are different from the actual conditions.

2. The regional government should place the employees in the finance department who understand the financial management process and have experiences and the ability to use computers.

\section{Reference}

[1] Dewi, S. A. N. T., and Dwirandra, A.: "Pengaruh Dukungan Manajemen Puncak, Kualitas Sistem, Kualitas Informasi, Pengguna Aktual dan Kepuasan Pengguna terhadap Implementasi Sistem Informasi Keuangan Daerah di Kota Denpasar,” E-Jurnal Akunt., pp. 196-214 (2013)

[2] Venkatesh, V., and Davis, F. D.: "A theoretical extension of the technology acceptance model: Four longitudinal field studies," Manage. Sci., vol. 46, no. 2, pp. 186-204 (2000) 